\title{
ОСОБЛИВОСТІ РОЗРОБЛЕННЯ КОНЦЕПТУАЛЬНОЇ МАТЕМАТИЧНОЇ МОДЕЛІ ПРОЦЕСУ РАННЬОГО ДІАГНОСТУВАННЯ СПАДКОВИХ ОРФАННИХ ЗАХВОРЮВАНЬ
}

\author{
В. 3. Стецюк, А. В. Малєй, О. І. Лісовиченко, \\ Н. О. Пічкур ${ }^{1}$, Л. Ю. Бабінцева ${ }^{2}$ \\ Національний технічний університет України \\ «Київський політехнічний інститут імені Ігоря Сікорського» \\ ${ }^{1}$ Національна дитяча спеціалізована лікарня «ОХМАТДИТ» \\ Міністерства охорони здоров'я України \\ ²Національна медична академія післядипломної освіти імені П. Л. Шупика
}

\begin{abstract}
Представлено особливості розроблення концептуальної моделі для раннього діагностування спадкових орфанних захворювань. Наведено ряд теоретичних положень, що використовуються в розробці. Запропоновано концептуальні підходи щодо формалізації представлення переліку орфанних захворювань у вигляді математичної моделі та розглянуто ступені зв'язків.
\end{abstract}

Ключові слова: орфанні захворювання, графр, симптом, вроджені помилки метаболізму, модель розпізнавання.

\section{FEATURES OF THE DEVELOPMENT OF A CONCEPTUAL MATHEMATICAL MODEL FOR THE PROCESS OF EARLY DIAGNOSTICS OF HEREDITARY ORPHAN DISEASES}

\author{
V. Z. Stetsiuk, A. V. Maliei, O. I. Lisovychenko, \\ N. O. Pichkur ${ }^{1}$, L. Yu. Babintseva² \\ National Technical University of Ukraine «Igor Sikorsky Kyiv Polytechnic Institute» \\ ${ }^{1}$ National specialized children hospital «OKHMATDYT» of the Ministry of Health of Ukraine \\ ${ }^{2}$ Shupyk National Medical Academy of Postgraduate Education
}

\begin{abstract}
The article deals with the development of a conceptual model for early diagnostics of hereditary orphan diseases. A number of theoretical positions used in the development are given. Conceptual approaches to formalizing the presentation of orphan diseases list in the form of a connected model are offered and the connection degrees are considered.
\end{abstract}

Key words: orphan diseases, graph, symptom, group of inborn errors of metabolism, recognition model. 


\title{
ОСОБЕННОСТИ РАЗРАБОТКИ КОНЦЕПТУАЛЬНОЙ МАТЕМАТИЧЕСКОЙ МОДЕЛИ ДЛЯ ПРОЦЕССА РАННЕГО ДИАГНОСТИРОВАНИЯ НАСЛЕДСТВЕННЫХ ОРФАННЫХ ЗАБОЛЕВАНИЙ
}

\author{
В. 3. Стецюк, А. В. Малей, О. И. Лисовиченко, \\ Н. А. Пичкур ${ }^{1}$, Л. Ю. Бабинцева ${ }^{2}$ \\ Национальный технический университет Украины \\ «Киевский политехнический институт имени Игоря Сикорского» \\ ${ }^{1}$ Национальная детская специализированная больница «ОХМАТДЕТ» \\ Министерства здравоохранения Украины \\ ${ }^{2}$ Национальная медицинская академия последипломного образования имени П. Л. Шупика
}

\begin{abstract}
Представлены особенности разработки концептуальной модели для ранней диагностики наследственных орфанных заболеваний. Приведен ряд теоретических положений, используемых в разработке. Предложены концептуальные подходы к формализации представления перечня орфанных заболеваний в виде математической модели и рассмотрены степени связей.
\end{abstract}

Ключевые слова: орфанные заболевания, граф, симптом, врожденные ошибки метаболизма, модель распознавания.

Вступ. Сьогодні розвиток такої науки, як генетика, значно пришвидшився. Вчені з України та інших країн активно працюють над класифікацією нині існуючих орфанних (метаболічних) захворювань, кількість яких вираховується вже тисячами. На жаль, лікувати ці захворювання сучасній медицині дуже складно. Проте своєчасне розпізнавання того чи іншого захворювання допомагає лікарям надавати своєчасну необхідну допомогу новонародженим. Варто зазначити, що історія хвороби пацієнтів центру метаболічних захворювань, на відміну від пацієнтів інших відділень, містить значно більше інформації, оскільки всі, без виключень, зовнішні чи внутрішні особливості пацієнтів мають велике значення.

На сучасному етапі розвитку лікарі-генетики змушені витрачати дорогоцінний час не на прийом пацієнтів, а на заповнення від руки історій хвороб пацієнтів, оскільки стандартні медичні програми для заповнення історій хвороб не мають відповідної класифікації. Саме для надання можливості лікарям-генетикам звільнитися від рутинної роботи з картками і створено розробку, що представляється.

При народженні дитина, яка має метаболічні захворювання, зазвичай має нормальний вигляд, але через декілька годин проявляються симптоми хвороби. Вроджені дефекти обміну речовин, при яких клінічні симптоми розвиваються повільніше, зазвичай характеризуються більш сприятливим протіканням. Діагностика таких порушень іноді може запізнюватись на місяці та навіть роки.
Початкові симптоми також неспецифічні та їх іноді помилково приймають за наслідки недіагностованого перинатального інсульту.

Діагностика зазвичай вимагає проведення спеціальних лабораторних досліджень. I якщо негайно не почати проводити лікування, більшість вроджених дефектів обміну речовин можуть призвести до смерті дитини. Необхідно намагатися до якомога швидшого встановлення діагнозу.

В Україні протягом останнього десятиріччя досягнуто певного прогресу в діагностиці та лікуванні рідкісних захворювань. Сьогодні у світі розроблена та застосовується високовартісна замісна ферментотерапія для таких захворювань, як мукополісахаридози, хвороба Гоше, хвороба Помпе, хвороба Фабрі. Ряд захворювань коригуються дієтотерапією (фенілкетонурія, гомоцистінурія, інші спадкові порушення обміну амінокислот), комплексним лікуванням із залученням кофакторної терапії та спеціалізованих лікувальних сумішей (мітохондріальні, епігенетичні хвороби, порушення окиснення жирних кислот та інші).

Одним із кроків на шляху до вирішення проблеми рідкісних захворювань у нашій країні $€$ створення Національного реєстру дітей з метаболічними захворюваннями. Робота в цьому напряму проводиться Центром орфанних захворювань Національної дитячої спеціалізованої лікарні «ОХМАТДИТ» (далі - Центр).

У Центрі впроваджено методи ферментодіагностики спадкових метаболічних хвороб накопичення, до яких відносяться і мукополісахаридози. 
Протоколи діагностики відповідають сучасним світовим стандартам. Розроблено та впроваджено методи дородової діагностики. Всі пацієнти з підтвердженим діагнозом внесені до реєстру пацієнтів із метаболічними хворобами.

3 метою зменшення навантаження на лікарів, медичних реєстраторів було розпочато розроблення програмного комплексу, одним із завдань якого $€$ раннє діагностування спадкових орфанних захворювань. Використовуючи вже існуючий формалізований досвід лікарів, програмне забезпечення покликано виконувати функції зберігання, оброблення, опрацювання даних i, як результат, повинно стати надійним помічником (як для лікарівгенетиків, так і для пацієнтів) виконувати функцію системи підтримки прийняття рішень.

Основою створення даного спеціалізованого програмного комплексу, безперечно, є створення логічного блоку, що відповідає за сам алгоритм розрахунків. Відтак, постало завдання формалізації в єдиній моделі зв'язків тисяч захворювань з одного боку, та сотень параметрів з історії хвороби з іншого боку. Варто зазначити, що автоматизація процесу діагностування за допомогою програмного комплексу докорінно відрізняється від процесу діагностування лікарями. Першою принциповою відмінністю $є$ те, що програмний комплекс покликаний лише допомогти лікарю підібрати варіанти вірного рішення в тій чи іншій ситуації, але остаточне рішення, безперечно, залишається за медичним працівником. Однак, з іншого боку, взявши на себе функції проведення великої кількості розрахунків, врахування досвіду історій пацієнтів, прогнозування, програмний комплекс може суттєво допомагати лікарю в прийнятті правильних рішень. Фактично все зводиться до розроблення та застосування якісної математичної моделі.

Математична модель дозволяє описати можливості досліджуваного об'єкта за допомогою системи формул математичних функцій і рівнянь. Наприклад, до математичних моделей природних явищ відносяться загальновідомі закони тяжіння, закон Ома. Для моделювання динамічних процесів використовується система диференційних рівнянь, що дають змогу відобразити зміну величин у дослідній системі за допомогою похідних. Математичне моделювання будь-якого процесу можливе лише за умови достатньої інформації щодо його фізичних і біологічних закономірностей. Але розвиток сучасних технологій, у тому числі інформаційних, дає змогу значно розширити можливості застосування саме математичної моделі в медицині не тільки для моделювання простих систем, але й для цілого комплексу складних.

Математичне моделювання дозволяє дослідити поведінку біологічних систем в умовах, що дуже складно й витратно відтворити в клінічному експерименті. Ще однією перевагою застосування математичної моделі $є$ скорочення часу дослідження, оскільки комп'ютер розбирає достатньо велику кількість можливих варіантів досліду за короткий проміжок часу. Також математична модель спрощує розв'язання завдань із лікування хвороб, оскільки вона прискорює аналіз вхідних даних і вирішення питань, що можуть виникнути в процесі лікування.

Розглянемо складові математичної моделі, що змогла б врахувати всі особливості взаємодії великої кількості орфанних захворювань та параметрів історії хвороби пацієнтів.

Мета дослідження: надати опис концептуальної математичної моделі процесу ранньої діагностики спадкових орфанних захворювань.

Результати та їх обговорення. Особливості моделювання вроджених помилок метаболізму. Геном людини складається з близько 25000 основних генів. Більшість 3 них виконують свої основні функції шляхом взаємодії з так званими малими молекулами та макромолекулами. Мережа, що виникає внаслідок всіх цих взаємодій, формує клітинні компоненти, зокрема білки та РНК [6]. Вроджені помилки метаболізму (ВПМ) є наслідком генетичної варіації, але фенотип хвороби формується не тільки внаслідок функціональної зміни ураженого генного продукту, а й з урахуванням поширення зав'язків по клітинних мережах [2].

Білки виконують клітинні функції, і всі білково-білкові зв'язки утворюють велику підмережу всередині людського організму [10]. Повна високоякісна карта мережі протеїнової взаємодії має принципове значення для розуміння захворювань [5]. Аналіз цих мереж з новими інструментами мережної медицини може допомогти зрозуміти клітинні механізми, що лежать в основі ВПМ, взаємозв'язків між різними ВПМ або між ВПМ та іншими захворюваннями.

Біологічні мережі не $€$ випадковими та регулюються сукупністю принципів. Вони не мають масштабу, тобто є багато вузлів з кількома сусідами та декілька вузлів з багатьма сусідами, які називаються центрами [2]. Асоційовані з хворобами білки не розсіюються випадковим чином, а мають 
тенденцію взаємодіяти один з одним [9]. Кластер пов'язаних з хворобами білків у тій самій мережі сусідів формує підграф, який є модулем хвороби [2]. Ці модулі можуть бути специфічними для тканини [8] та персоналізованими пучками експресії генів, які пов'язані з цими модулями, на вплив окремих виразів хвороби [3]. У межах модуля хвороби різні захворювання можуть виникати з загальних механізмів і відображати перехресні фенотипи, як це показано для складних захворювань, таких як запалення, бронхіальна астма та серцево-судинні захворювання [3].

Однак підходи до мережної медицини не були використані для систематичного вивчення ВПМ [1] як гетерогенної групи порушень, що впливають практично на всі біохімічні шляхи людини та погіршують функцію багатьох органів [11]. Ієрархічна класифікація ВПМ, надана Товариством вивчення вроджених помилок метаболізму (Society for the Study of Inborn Errors of Metabolism, SSIEM), містить 612 захворювань з числами МIM [4] у 15 групах захворювань [7]. Використовуючи нові інструменти мережної медицини, можна дослідити, чи є суб'єкт ВПМ справді організованим як модулі захворювання у взаємодію білкових зв'язків, і як вони пов'язані один з одним.

Для подальшого поліпшення клінічної значимості стратегії було розглянуто відносини ВПМ з іншими захворюваннями, не пов'язаними з ВПМ, інтегровану базу даних, таку як функціональні анотації з генної онтології, фенотипні ознаки та посилання на ліки або біологічно активні сполуки.

Далі структуровано висвітлимо відомі зв'язки в групах ВПМ, оскільки на цьому і буде побудована подальша математична модель програмного забезпечення.

Взаємозв'язок ВПМ. В роботі [3] генотип людини подається як сукупність 13460 білків, зв'язаних 141296 стійкими зв'язками. Відповідно до класифікації SSIEM, 427 генів можуть асоціюватися з ВПМ, а 376 їх результуючих генів, ВПМ-асоційованих білків, були ідентифіковані в людському організмі. У межах набору з 376 ВПМ-асоційованих білків, 298 білків встановили 706 взаємодій (табл. 1) між собою, що призвело до можливого подання ВПМ у вигляді графу (рис. 1). В результаті схематично граф ВПМ сформувався в 7 компонентів (рис. 1), кожен з яких містить щонайменше 3 вузли, причому найбільший з'єднаний компонент містив 168 білків, пов'язаних з ВПМ із 14 з 15 груп ризику (табл. 2). Другий за величиною пов'язаний компонент з 22 вузлами головним чином складався з білків, пов'язаних із порушеннями енергетичного обміну (група 4), тоді як дев’ять білків, які утворили третій за величиною пов'язаний компонент, пов' язані з порушеннями амінокислот і пептидного обміну (група 1) та розладами в обміні вітамінів та (небілкових) кофакторів (група 13).

Таблиця 1

Параметри мережі білків в організмі людини та ВПМ

\begin{tabular}{|l|c|c|}
\hline & $\begin{array}{l}\text { Взаємодія в ор- } \\
\text { ганізмі людини }\end{array}$ & ВПМ \\
\hline Ребра графу & 13460 & 298 \\
\hline Вершини графу & 141296 & 706 \\
\hline $\begin{array}{l}\text { Зв’язані компоненти } \\
\text { (кількість вершин >3) }\end{array}$ & 3 & 7 \\
\hline $\begin{array}{l}\text { Компонент з най- } \\
\text { більшою кількістю } \\
\text { зав’язків }\end{array}$ & 13329 & 168 \\
\hline $\begin{array}{l}\text { Середній коефіцієнт } \\
\text { кластеризації }\end{array}$ & 0,17 & 0,32 \\
\hline $\begin{array}{l}\text { Середнє значення } \\
\text { зв’язки }\end{array}$ & 21 & 4 \\
\hline
\end{tabular}

Ступінь вузла в межах мережі (рис. 1) описує кількість з'єднань з іншими вузлами, у випадку мережної взаємодії з білками кількість взаємодій даного білка встановлюється з іншими білками. Як показано раніше для інших біологічних мереж, ступінь розподілу ВПМ має певну закономірність, що вказує на масштабну біологічну мережу з багатьма білками з низьким ступенем і декількома білками з високим ступенем (рис. 2). Аналіз ВПМ показав, що в середньому ВПМ-асоційовані білки мають лише чотири партнера по взаємодії, тоді як середній ступінь взаємодії в людини становить 21. Високозв'язані вузли беруть на себе специфічні біологічні ролі і можуть бути розділені. Вони можуть або утворювати центральний вузол в межах модуля або підключати кілька підграфів у мережі. В межах ВПМ було ідентифіковано 45 вузлів зі ступенем зв'язку $\geq 10$. Коефіцієнт кластеризації вузла описує тенденцію, з якою сусіди цього вузла також взаємодіють один з одним. Середній коефіцієнт кластеризації (cl) ВПМ становив 0,32; таким чином, він більший, ніж для людського організму (cl, 0,17). 


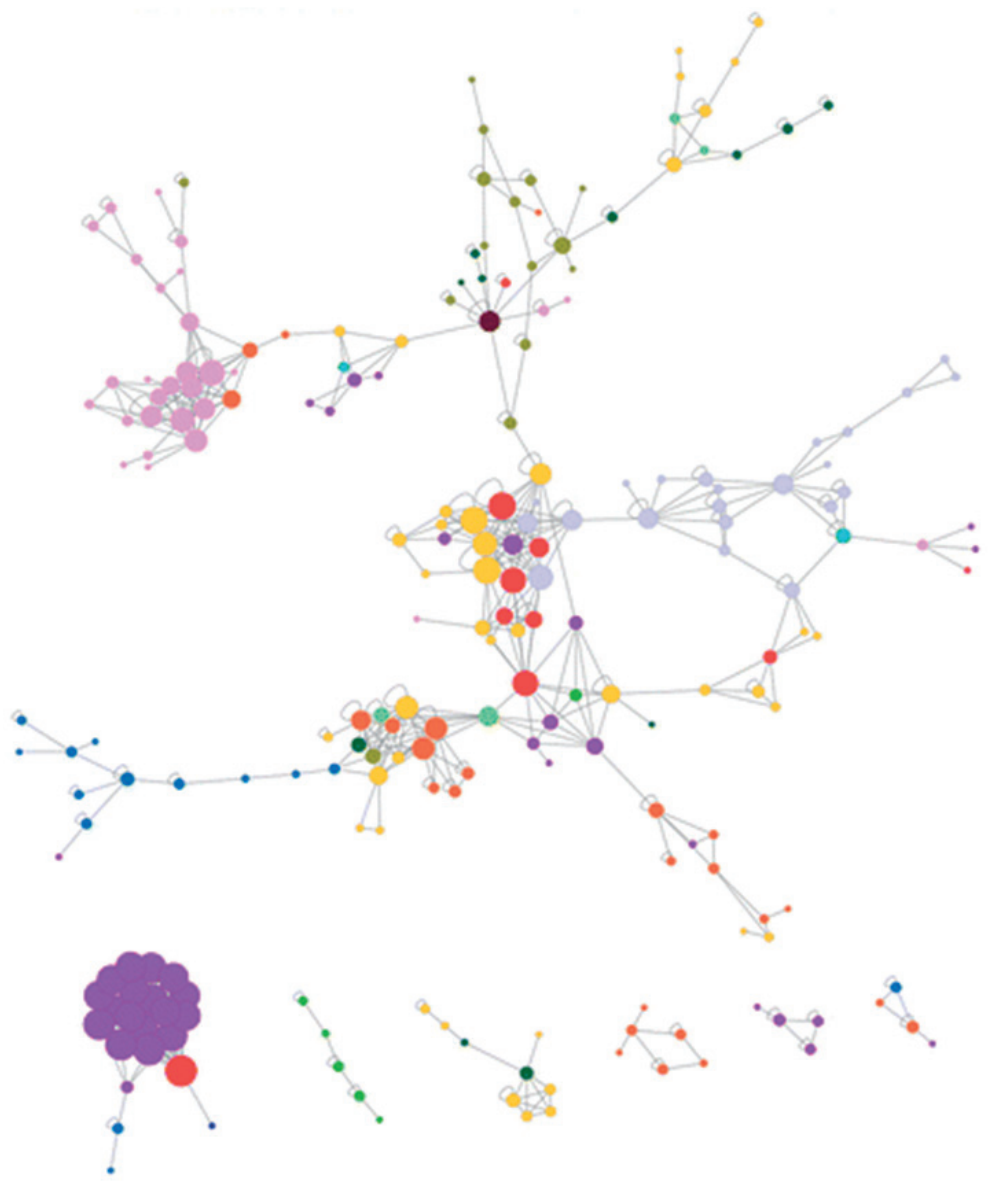

Рис. 1. Схематичне зображення зв'язків семи найбільших груп ВПМ

Таблиця 2

\section{Перелік груп захворювань на графі}

\begin{tabular}{|c|l|}
\hline № 3/п & \multicolumn{1}{|c|}{ Група захворювань } \\
\hline I & Порушення обміну амінокислот і пептидного метаболізму \\
\hline II & Розлади вуглеводного обміну \\
\hline III & Порушення обміну жирних кислот та кетонів \\
\hline IV & Порушення енергетичного обміну \\
\hline V & Розлади в метаболізмі пуринів, піримідинів та нуклеотидів \\
\hline VI & Розлади метаболізму стеринів \\
\hline VII & Розлади порфірину та метаболізму гема \\
\hline VIII & Розлади обміну ліпідів та ліпопротеїдів \\
\hline IX & Вроджені порушення глікозилування та інші порушення модифікації білка \\
\hline X & Лізосомальні розлади \\
\hline XI & Пероксисомальні розлади \\
\hline XII & Розлади метаболізму нейромедіаторів \\
\hline XIII & Розлади в метаболізмі вітамінів та (небілкових) кофакторів \\
\hline XIV & Розлади в метаболізмі мікроелементів та металів \\
\hline XV & Розлади метаболізму ксенобіотиків \\
\hline
\end{tabular}




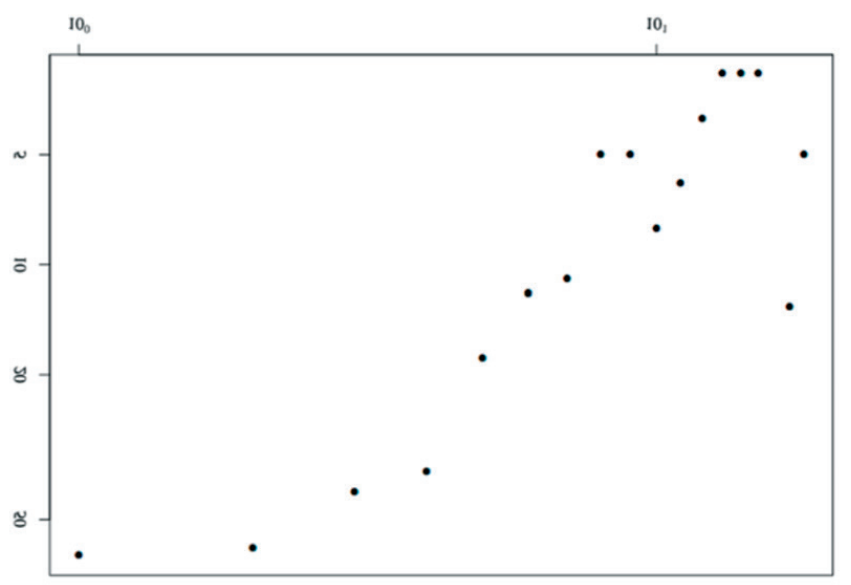

Рис. 2. Співвідношення значення кількості вершин у вузлі (вісь Ү) до ступені білка (вісь X)

Діаметр — найбільша відстань між будь-якими двома парами вузлів у мережі. Діаметр дорівнює 22 для ВПМ та 13 для людського організму. Найбільша зв'язана складова ВПМ $(168, \mathrm{z}=5,3)$ була більшою, ніж випадкове очікування $(52,4)$, тоді як середня коротка відстань ВПМ-пов'язаних білків на основі мережі була меншою $(1,34, \mathrm{z}=10,1)$, ніж випадкове очікування $(1,81)$.

Взагалі, результати аналізу мережних заходів найбільшого пов'язаного компонента та середньої найкоротшої відстані підтримують уявлення про те, що ВПМ-асоційовані білки мають тенденцію знаходитись у тому самому сегменті мережі в людському організмі. Крім того, існує два різних шаблони кластеризації в ВПМ. Білки, пов’язані з певними групами захворювання, створювали досить однорідні кластери і, отже, відокремлювалися від інших ВПМ-асоційованих білків. Білки, пов'язані з іншими групами захворювань, також сприяли гетерогенним кластерам, центральним елементам найбільшого зв'язаного компонента, або вони були розподілені по віддаленим областям мережі.
Далі розглянемо відомі модулі в групах ВПМ, оскільки це також буде відігравати важливе значення у фінальному поданні концептуальної математичної моделі комплексу.

Модулі захворювань ВПМ. Для перевірки гіпотези про модулі захворювання для кожної з груп ВПМ-інфекції захворювань, що відповідає класифікації SSIEM, було розраховано мережні міри найбільшої пов'язаної компоненти та середні короткі відстані для всіх груп хвороб (рис. 3). Аналіз проводився для всіх ВПМ-асоційованих білків, що відтворювали взаємодію в людини (n, 376). Групи аналізу захворювань 6 (порушення метаболізму стеринів) та 15 (порушення обміну ксенобіотиків) були виключені з аналізу через низьку кількість пов'язаних з ними білків чи відсутність взаємодій. Групи IEM захворювання порівнювалися з наборами вузлів з відповідним числом вузлів, що представляли загальні характеристики людської взаємодії. Було розраховано бали за кожне порівняння і в результаті 13 груп захворювань встановили значні модулі захворювання (найбільший зв'язний компонент, z-показники >1,6, середня найкоротша відстань, z<1,6). Найбільші модулі захворювання були ідентифіковані для лізосомних хвороб (25 вузлів), пероксисомних хвороб (22 вузли) та розладів енергетичного обміну (18 вузлів). Три модулі середнього розміру, що виникли внаслідок груп ризику 1, 5 та 8, були менш взаємопов'язаними. Решта модулів не були взаємопов'язаними (група захворювань 7) або були дуже малими (групи захворювань 12-14).

Далі необхідно дослідити зв'язки між групами захворювань ВПМ на основі білкових взаємодій (рис. 4). На цьому рівні можна виявити 211 взаємодій між білками, що належать до різних груп захворювань. Розлади амінокислотного і пептидного метаболізму (група 1 хвороби) мали центральне місце в цій мережі. Ця група - сформована підмережа

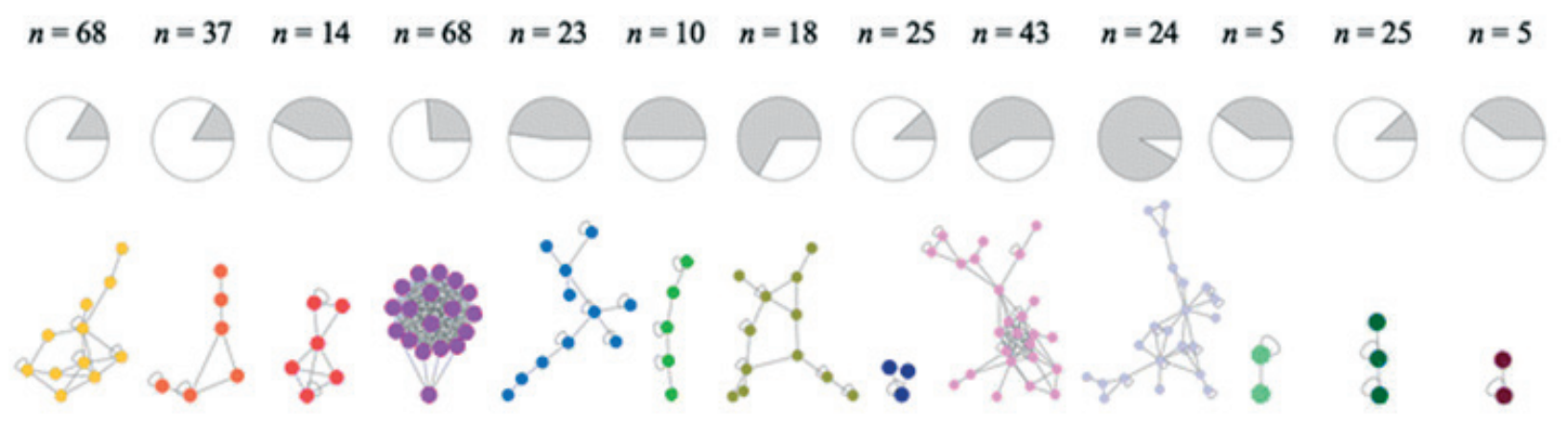

Рис. 3. Ідентифікація модулів груп захворювань у межах ВПМ 


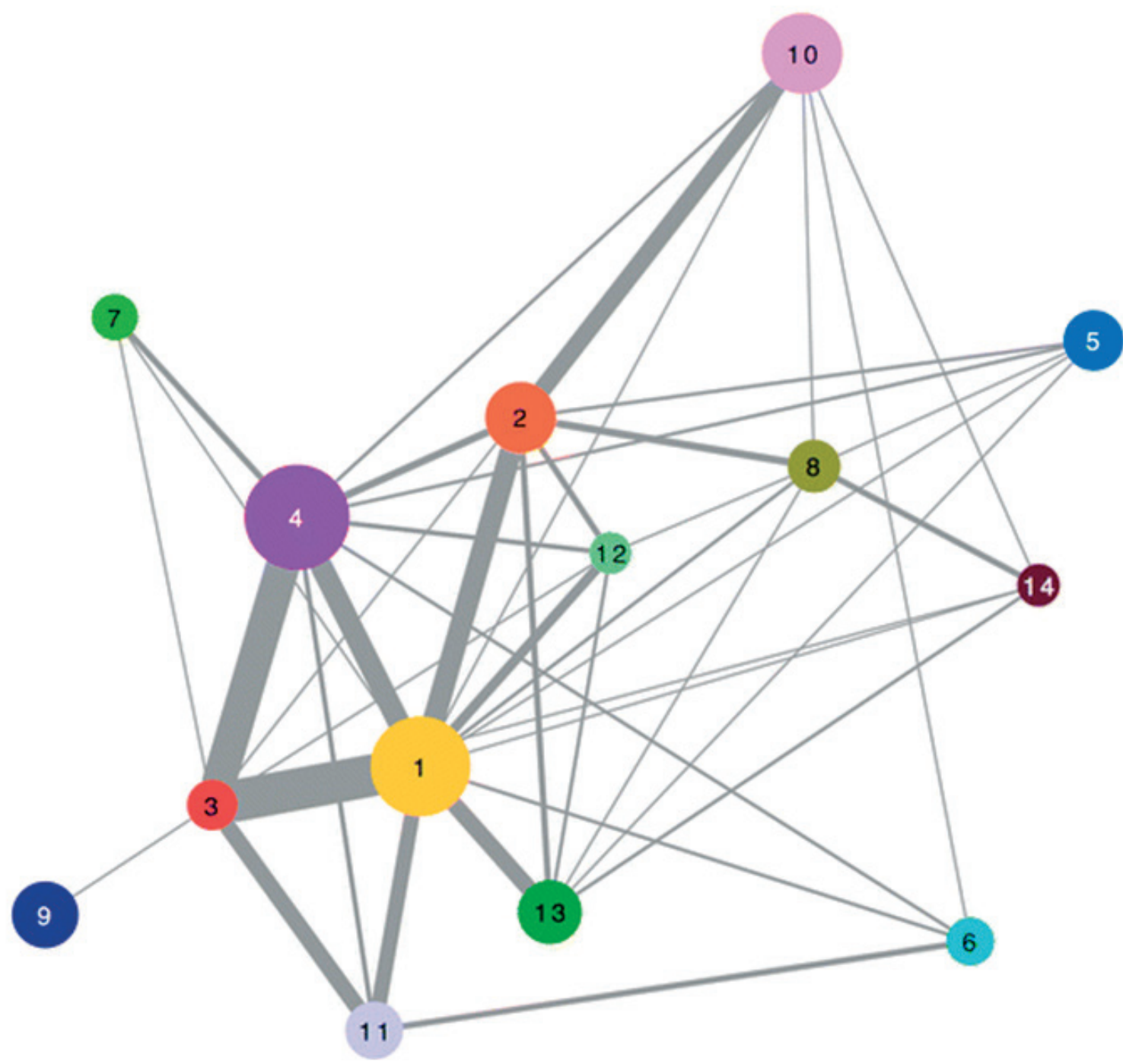

Рис. 4. Граф зв'язків між різними групами метаболічних захворювань

разом з порушеннями вуглеводного обміну (група 2), порушенням жирних кислот і метаболізму кетонових тіл (група 3), а також порушенням енергетичного обміну (група 4), які становлять 44\% всієї взаємодії між групами захворювань.

Групи захворювань з високим ступенем самоорганізації, тобто де є багато вузлів, що належать до однієї і тієї ж групи захворювань, організовані в межах конкретного модуля (групи 5, 7, 8, 10, 11), мали невеликий ступінь взаємодії з іншими групами хвороб. У випадку груп хвороб, що демонструють низький ступінь самоорганізації, тобто лише невелика частина вузлів організована в рамках конкретного модуля, ступінь взаємозв'язку з іншими групами захворювань збільшується (групи 1, 2, 4) . Також виділено групи захворювань 3 високим ступенем взаємодії - опосередкованої взаємодії з іншими ВПМ. Особливий випадок представляла група захворювань 3 (розлади обміну жирних кислот та метаболізму кетонових тіл). Тут ми спостерігали комплексний специфічний модуль захворювання, в якому половина білків, що входили до групи захворювань, сприяли модулю. На додаток до цього досить високого ступеня самоорганізації були встановлені сильні взаємодії з групами захворювань 1 (порушення амінокислотного і пептидного обміну), 4 (порушення енергетичного обміну) та 11 (пероксисомальні розлади) та слабкі взаємодії з групами захворювань 2, 7, 9 і 12.

Висвітлений у даній статті опис математичної моделі є загальним і стосується тільки самих основних принципів взаємодій. Подальший опис математичної моделі детальніше буде подано в наступних статтях. 
Висновки. Запропоновано концептуальну математичну модель процесу раннього діагностування спадкових метаболічних захворювань, що безпосередньо є базою для створення інформаційноаналітичної системи. Формалізовано в єдиній системі схеми ВПМ, особливості їх взаємодії та їх розподіл на модулі.

Дана пропозиція має важливе значення, оскільки на сьогодні в Україні відсутнє спеціалізоване програмне забезпечення в сфері діагностики орфанних захворювань через що часто втрачається дорогоцінний час. Існуючі протоколи діагностування пацієнтів підходять лише для роботи лікаря (тобто людського розуму), але в початковому вигляді не можуть бути правильно застосовані в програмному забезпеченні. Створення нової єдиної інформаційно-аналітичної системи на базі наведеної математичної моделі може суттєво покращити ефективність процесу діагностування.

\section{Література.}

1. A next generation multiscale view of inborn errors of metabolism / C. A. Argmann, S. M. Houten, J. Zhu, E. E. Schadt // Cell. Metab. — 2016. — Vol. 23, No. 1. P. 13-26.

2. Barabási A. L. Network medicine: a networkbased approach to human disease / A. L. Barabási, N. Gulbahce, J. Loscalzo // Nat. Rev. Genet. — 2011. - Vol. 12. - P. 56-59.

3. Integrating personalized gene expression profiles into predictive disease-associated gene pools / J. Menche, E. Guney, A. Sharma [et al.]. — Syst. Biol. Appl. — 2017. - Vol. 3. - P. 10.

4. ОМIM - Online Mendelian Inheritance in Man [Електронний ресурс] // Режим доступу : www.omim.org.

5. Proteome-scale human interactomics / K. Luck, G. M. Sheynkman, I. Zhang, M. Vidal //Trends Biochem. Sci. - 2017. - Vol. 42, No. 5. - P. 342-354.

6. Schadt E. E. Molecular networks as sensors and drivers of common human diseases / E. E. Schadt // Nature. 2009). - Vol. 461, No. 7261. - P. 218-223.

7. SSIEM: Society for the Study of Inborn Errors of Metabolism [Електронний ресурс] // Режим доступу: www.ssiem.org/resources/IEC.asp.

8. Tissue specificity of human disease module / M. Kitsak, A. Sharma, J. Menche, [et al.] // Nat. Sci. Rep. — 2016. — Vol. 6. - P. 35241.

9. The human disease network / K. Goh, M. Cusick, D. Valle [et al.] // Proc. Natl. Acad. Sci. — 2007. Vol. 104, No. 21. - P. 8685-8690.

10. Vidal M. Interactome networks and human disease / M. Vidal, M. E. Cusick, A. L. Barabási. // Cell. — 2011. — Vol. 144, No. 6. — P. 986-998.
11. Woidy M. Inborn errors of metabolism and the human interactome: a systems medicine approach. M. Woidy, A. C. Muntau, S. W. Gersting // J. Inherit. Metab. Dis. — 2018. — Vol. 41, No. 3. — P. 285-296.

\section{References.}

1. Argmann, C. A., Houten, S. M., Zhu, J., \& Schadt, E. E. (2016). A next generation multiscale view of inborn errors of metabolism. Cell Metab., 23(1), 13-26. doi. rg/10.1016/j.cmet.2015.11.012.

2. Barabási, A. L., Gulbahce, N., \& Loscalzo, J. (2011). Network medicine: a network-based approach to human disease. Nat. Rev. Genet., 12, 56-59.

3. Menche, J., Guney, E., Sharma, A., Branigan, P. J., Loza, M. J., Baribaud, F., Dobrin, R. \& Barabási, A. L. (2017). Integrating personalized gene expression profiles into predictive disease-associated gene pools. Syst. Biol. Appl., 3, 10. doi:10.1038/s41540-017-0009-0.

4. OMIM - Online Mendelian Inheritance in Man. (n. d.). Retrieved from: www.omim.org.

5. Luck, K., Sheynkman, G. M., Zhang, I., \& Vidal, M. (2017). Proteome-scale human interactomics. Trends Biochem. Sci., 42(5), 342-354. doi: 10.1016/j. tibs.2017.02.006.

6. Schadt, E. E. (2009) Molecular networks as sensors and drivers of common human diseases. Nature, 461(7261), 218-223. doi: 10.1038/nature08454.

7. SSIEM: Society for the Study of Inborn Errors of Metabolism. (n. d.). Retrieved from: www.ssiem.org/ resources/IEC.asp.

8. Kitsak, M., Sharma, A., Menche, J., Guney, E., Ghiassian, S. D, Loscalzo, J., \& Barabási, A. L. (2016). Tissue specificity of human disease module. Sci. Rep., 6, 35241. doi: 10.1038/srep35241.

9. Goh, K., Cusick, M., Valle, D., Childs, B., Vidal, M., \& Barabási, A. L. (2007). The human disease network. Proc. Natl. Acad. Sci., 104(21), 8685-8690. doi. org/10.1073/pnas.0701361104.

10. Vidal, M., Cusick, M. E., \& Barabási, A. L. (2011). Interactome networks and human disease. Cell, 144(6), 986-998. doi: 10.1016/j.cell.2011.02.016.

11. Woidy, M., Muntau, A. C., \& Gersting, S. W. (2018). Inborn errors of metabolism and the human interactome: a systems medicine approach. J. Inherit. Metab. Dis., 41(3), 285-296. doi: 10.1007/s10545-018-0140-0. 